\title{
INDUSTRY-BASED CAPSTONE DESIGN PROJECTS: MEMORIAL'S FORTY YEARS EXPERIENCE
}

\author{
Leonard M. Lye, PEng, PhD, FCSCE, FEC \\ Professor and Chair of Civil Engineering \\ Faculty of Engineering and Applied Science, \\ Memorial University, St. John's, NL, A1B 3X5. \\ llye@mun.ca \\ Stephen E. Bruneau, PEng, PhD \\ Assistant Professor \\ Faculty of Engineering and Applied Science, \\ Memorial University, St. John's, NL, A1B 3X5. \\ sbruneau@mun.ca
}

\begin{abstract}
Over the last few decades, the idea that the engineering profession should have a significant input to engineering education has taken a stronghold throughout the world. This is still true today. At Memorial University of Newfoundland, professional contacts were deliberately built into the undergraduate program when it was developed in 1969. First, the program would run on the cooperative model whereby students alternate between industry and university and second, the traditional final-year individual theses would be discarded in favour of team-oriented comprehensive capstone design projects supplied by industry and supervised by professional engineers from industry and academia. Both aspects of the program require considerable interaction between students and faculty on one hand and the practicing engineering community on the other. This has considerably strengthened the ties between industry and academia and has given the students an appreciation of the significance of their work to society in which they live. This paper will highlight some of Memorial's experiences with industry-based capstone design projects over the last 40 years.
\end{abstract}

\section{Introduction}

Over the last few decades, the idea that the engineering professions should have significant input to engineering education has taken a strong hold throughout the world. Different countries have responded to this feeling in different ways and in the USA and Canada, the response has been a noticeable growth in co-operative education, a system whereby industry and the Universities co-operate in educating future professionals. This model is similar to the sandwich system used in the United Kingdom. The co-operative or sandwich system also involves an evaluation of the student's professional performance which may, in some cases, result in the student being required to leave the program. At Memorial University for instance, academic terms and the co-operative work terms are treated with equal status.

At Memorial University all six engineering programs are co-operative programs. In addition, the Civil Engineering program has integrated professional practice into the academic program through the use of industry-based capstone design projects. The engineering degree programs at Memorial University began in 1969 and superseded a three-year diploma program established in 1930. When the Civil Engineering courses were drawn up, it was decided then to replace the traditional individual research dissertation in favour of a comprehensive team-based capstone design project from industry. This is operated to develop the same characteristics of initiative and self-learning but oriented much more towards professional practice.

Design projects are, of course, common in such areas as construction and structural engineering. However, it was thought that a final year design project could only 
be successful if it required the student to draw on a broad range of experience and if it was organized in such a way as to simulate professional engineering practice as closely as possible. There seemed little point in developing a project that might be perceived as just another academic exercise.

It is of interest to note that the Canadian Engineering Accreditation Board (CEAB) in recent years has actually required that an engineering program must culminate with a significant design experience. Clause 3.3.4.4 states: The engineering curriculum must culminate in a significant design experience conducted under the professional responsibility of faculty licensed to practise engineering in Canada, preferably in the jurisdiction in which the institution is located. The significant design experience is based on the knowledge and skills acquired in earlier work and it preferably gives students an involvement in team work and project management (CEAB, 2008). Memorial's Civil Engineering program has been providing the significant design experience for the last forty years, and in fact, we require that not only the academic supervisors are registered professional engineers; we also ensure that all design projects are industry-based and jointly supervised by senior engineers from the industrial clients.

The purpose of this paper is to share our long experience with running our industry-based capstone design projects with Universities thinking of following our model. The process of running the capstone design project from project solicitation to final grading and awards will be described.

\section{Civil Design Projects}

As presently constituted, the capstone design project in the final academic term (academic term 8), is run by forming small student groups or 4 to 5 students, which operate as much as possible, in the manner of a professional consulting firm. One objective of the project course is the application of academically acquired knowledge to an actual design problem under conditions similar to those encountered in practice. The student "consultants" thus act as a team as they would in a consulting engineer's office and are subjected to the same constraints regarding information and deadlines. The course is instructed by one or two faculty members who arrange the individual projects in consultation with a number of professional engineers from the local engineering community. Engineers are approached several months before the course is due to begin and are asked if they can provide a suitable project. They are also requested to act essentially as clients/supervisors to give students an appreciation of the client-consultant relationship that will be experienced after graduation. Over the years, most of the clients are former students who have gone through the same process.

The client and the faculty develop the projects for the course in accordance with certain priorities. For example, it is considered important for students to gain some experience in integrating the various courses within their program. Design projects covering a range of civil engineering work are therefore given a higher priority. For example, a project that encompasses structural analysis and design, geotechnical design, hydraulic analysis and design, environmental considerations, cost estimating and project management, would be given preference over a project that required only a laboratory study or only some structural analysis. In general, the projects are very true to life and have been selected from work currently underway in the client's office.

The scope of the design project may seem large for a 4 month period, but it must be borne in mind that most of our students have an equivalent of 2 years of working experience through their co-operative work terms and are not novices.

\section{How the course is run}

At the beginning of the final semester a kick-off meeting is held in which the instructor provides the students a copy of the Course Guide detailing the schedule, deliverables, marking schemes, writing and presenting formats, expectations of students and clients, requisite forms etc. The students are then organized into consulting groups, normally 4 to 5 per group. This is achieved in one of two ways - students can be given the freedom to form their own groups, or,

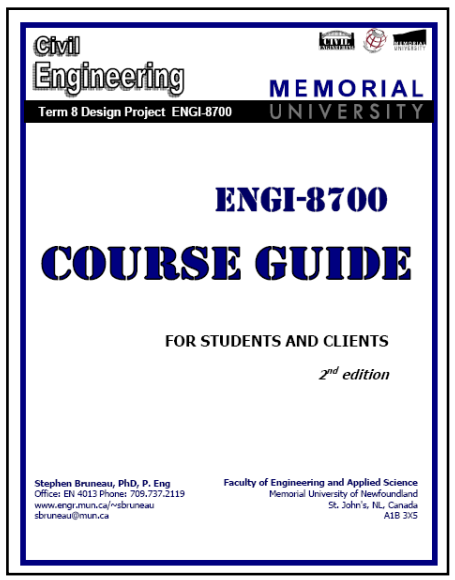


prior to the next meeting known as "the interview prequalification class" or simply the Prequal. In an effort to enable the students some degree of choice in what project their group will be assigned, they are requested to select from amongst all projects those that most interest them. In this way the clients will interview only those groups that have pre-negotiated for one of the limited interview time slots during the main matching event. At the end of the Prequal the interview schedule is finalized, sent to the clients and the student groups are given approximately one week to develop a detailed and professional statement of qualifications (SOQ).

The student groups are encouraged to be as professional and business-like as possible when dealing with the clients. Each group would have a business name and website, each member of the team has a title and business card, and the SOQs are typically exceptionally well-prepared. These documents are posted on-line and forwarded to the respective clients for consideration prior to the evening of the interviews or "Match night" as it is better known. This main matching event occurs approximately 10 days after the start of the semester. It consists of a series of short presentations by all clients to all students groups, followed by a break out, snacks, and then the commencement of the interviews as determined in the Prequal. Once all interviews are complete (10 minutes each) the clients are asked to privately rank the groups they met and likewise the student groups do the same. The instructor thus matches the clients with their preferred student consultants and in the event of a tie, the ranking of clients provided by the students determines the match. Thus all groups and clients are paired by the end of the evening, the results are announced and the matched parties plan their first meeting and the project work officially commences.

\begin{tabular}{|c|c|c|}
\hline \multirow[b]{2}{*}{ Timeline } & \multicolumn{2}{|c|}{$\begin{array}{c}\text { Activity Timeline for ENGI } 8700 \\
\text { (slightly varies with calendar year to year) }\end{array}$} \\
\hline & Student Activity & Client Activity \\
\hline $\begin{array}{r}\text { (Optional) } \\
\text { Months Prior }\end{array}$ & Provide list of sub discipline interests & $\begin{array}{l}\text { Provide written project description } \\
\text { and student requirements }\end{array}$ \\
\hline $\begin{array}{r}\text { Week } 1 \\
\text { in January }\end{array}$ & $\begin{array}{l}\text { Student grouping announced or } \\
\text { selected, groups prequalify clients, } \\
\text { groups develop Statement of } \\
\text { Qualifications (SOQ) }\end{array}$ & \\
\hline Week 2 & $\begin{array}{l}\text { Submit SOQs, attend match night } \\
\text { (interviews \& first meeting with client) }\end{array}$ & $\begin{array}{l}\text { Review SOQS, Attend match night } \\
\text { (present project inteview groups, } \\
\text { have first meeting with match } \\
\text { group) }\end{array}$ \\
\hline Week 3 & Project work, meetings, lectures & Regular meeting with students \\
\hline Week 4 & Submit work plan & Regular meeting with students \\
\hline Week 5 & Project work, meetings, lectures & Regular meeting with students \\
\hline Week 6 & Project work, meetings, lectures & Regular meeting with students \\
\hline Week 7 & $\begin{array}{l}\text { Term break, submit progress report, } \\
\text { give presentations }\end{array}$ & $\begin{array}{l}\text { Attend Progress Report } \\
\text { Presentations (optional) Provide } \\
\text { feedback to instructor }\end{array}$ \\
\hline Week 8 & Project work, meetings, lectures & Regular meeting with students \\
\hline Week 9 & Project work, meetings, lectures & Regular meeting with students \\
\hline Week 10 & Project work, meetings, lectures & Regular meeting with students \\
\hline Week 11 & Project work, meetings, lectures & Regular meeting with students \\
\hline Week 12 & Project work, meetings, lectures & Regular meeting with students \\
\hline $\begin{array}{r}\text { Week } 13 \\
\text { in April }\end{array}$ & $\begin{array}{l}\text { Submit final report, final presentations, } \\
\text { individual binders }\end{array}$ & $\begin{array}{l}\text { Attend final presentations, provide } \\
\text { feedback to instructor }\end{array}$ \\
\hline
\end{tabular}

Following the initial meeting with the client, who provides typical clients' requirements and supplies such as technical information as would normally be available, the students carry the project to completion in accordance with the data they have been given.

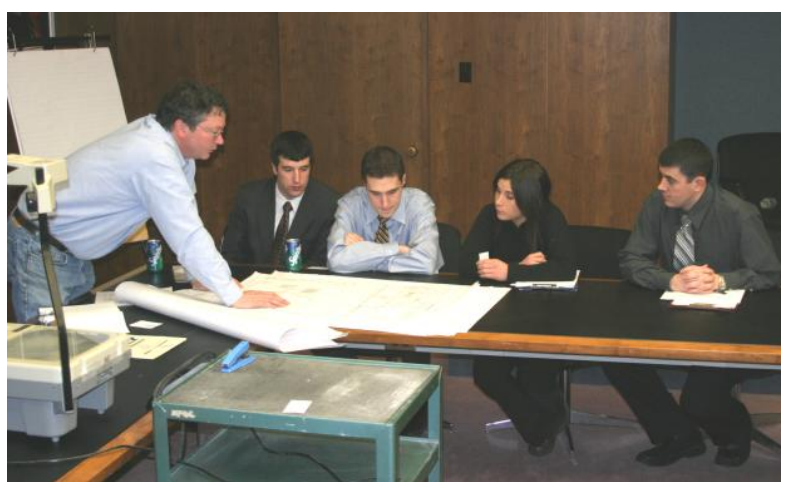

Client meeting with student consultants.

Approximately four weeks into the semester the students encounter their next major milestone: the submission of a work plan to both the instructor and the client. The plan must reflect all work tasks and subtasks, resources, schedule and methodology of execution in a way that demonstrates a grasp of the scope of project execution at hand. In addition, the plan helps ensure that individual students do not carry an inappropriate proportion of the total load. The approval of both course instructor and client is necessary before proceeding with detailed work.

Often, each group receives additional support/supervision by faculty member other than the course instructor. Knowledge of the various branches of civil engineering is necessary to cope with interdisciplinary projects and the students are encouraged to discuss problems with any faculty with particular expertise in the area for which specialized advice is required. A high degree of co-operation is therefore required from colleagues of the Faculty. This is usually not a problem as it is generally agreed that the capstone design project is the responsibility of every faculty to make it a success.

The course instructor(s) monitor the progress of each project by having regular meetings with each group at least once a week. Groups also meet with the client at least once a week when possible. The purpose of the weekly meetings with the course instructor(s) is to ensure that every member of the team is carrying their fair share of the work. In addition, the course instructor(s) also make sure that the clients are not expecting too much or too little. For example, a client may only require the group to look at only one 
alternative. If the instructor(s) think that this is not academically challenging enough, he or she may require that the group look at a few more alternatives even though it is not asked to do so by the client.

A recent innovation in the execution of the course involves a regular weekly business meeting with all students in attendance. The meeting proceeds according to strict Board rules in that the instructor, as chair, calls the meeting to order and then proceeds through the formalities of reviewing previous minutes, old business, new business etc - though the primary activity is the very brief public report given by a representative of each group plainly explaining the progress made, problems encountered, and plan for the next week. This mini-report is presented and submitted forming a continuous record of each group's progress, and formally documents raised issues - a very helpful tool for the instructor. The highlight of the business meeting, typically, is the scramble for a motion to adjourn.

At the halfway point in the semester groups are again responsible for delivering a report. The progress report is also summarized in a presentation in which all members of the groups play a role. In this way the students obtain some exposure and practice for the final presentation for which the clients will be present. Recently these presentations have been video recorded and provided to the respective groups for their own discrete review and critique.

The final reports are delivered in the final week of classes and a formal presentation session is broadly attended by interested professors, clients, graduate students, and of course the instructor(s) and all student groups. Thus in summary the hard copy deliverables for each group are:

1. Statement of Qualifications (SOQ)

2. Project Work Plan

3. Mid term Progress report

4. Copy of progress report presentation

5. Final report

6. Report appendices, drawings, programs. . .

7. Copy of final report presentation

8. Project binder including meeting minutes, resumes, calculations, etc

The faculty instructor(s) in liaison with the client engineers and supporting faculty conduct the evaluation of the completed project. Marks are awarded on the basis of the preliminary and final reports, drawings and specifications, cost estimates, etc., and on the group's performance at an oral presentation open to all members of the Faculty and all project clients. Allowance is also made for subjective modification of these marks based on weekly progress meetings and frequent personal contact and the client's feedback. At Memorial, the group that gives the best presentation and best overall project are given prizes. Judging is done by a panel of judges comprising the clients and faculty members.

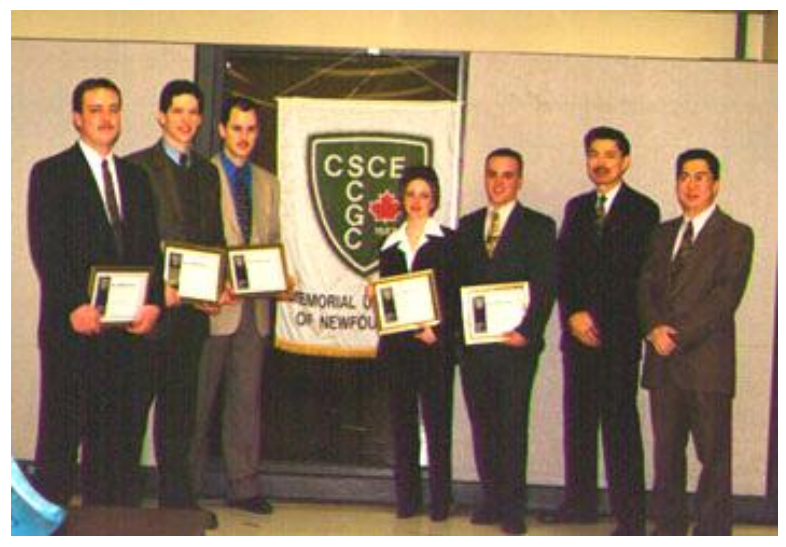

The CSCE Prize is awarded for the best group presentation

\section{Sample projects and requirements}

A wide variety of projects have been undertaken over the last 40 years. They have been selected from all branches of civil engineering with clients from major oil and gas companies, small local and international consultants, federal and provincial government departments, public utilities, and design-build contractors. Some typical projects and requirements are listed below:

i) Design of an airstrip in a remote region of Labrador: (a) undertake siting alternatives; (b) investigate alternatives for design aircraft; (c) design of airstrip and associated works; (d) investigate the use of navigation aids; and (e) prepare design briefs, drawings, and cost estimates.

ii) Preparation of an emergency preparedness plan (EPP) for an hydroelectric system: (a) perform a review of literature and information available; (b) determine failure scenarios; (c) establish alarm levels based on failure modes; (d) investigate methods of evacuation; (e) evaluate sensitivity using mathematical models; and (f) recommend EPP, organizational plan, and estimate cost. 
iii) Complete design of a 100-m flare tower for a FPSO: (a) preliminary design with loads calculations; (b) study of tower cross section alternatives; (c) bracing study and structural analysis; (d) dynamic and fatigue analysis; (e) final design, drawings, and cost estimates.

iv) Modernization of a spillway: (a) flood routing of inflow design flood to check adequacy of the spillway; (b) stability analysis of the structure to check safety against ice and hydrostatic loads; (c) preliminary design of strengthening measures; (d) development of a scheme for retrofitting with vertical lift gates and associated works; (e) constructability study, including preparing a schedule, cost estimate, and drawings.

v) Interim Landfill design and Waste Transportation Study: In compliance with the new Provincial Waste Management and Consolidation Strategy: (a) design the landfill and conduct a study on the transportation practices that are involved with collecting the solid waste and bringing it to the appropriate site. (b) to provide a written report and a presentation to the client, and client's client outlining the design plans for the landfill site and the findings of the transportation study. (c) a cost estimate and recommendations for the communities of concern.

vi) Improvements to a major highway interchange for improved traffic flow efficiency. (a) design alternatives to improve the interchange/intersection capacity must be considered to improve level of service for the current traffic volume and projected future traffic volume. (b) Consideration of the current level of service of the intersections with the interchange. (c) look at alternatives to improve the interchange and traffic flow and the costs associated with the alternatives. (d) Proposal of a final solution or solutions in a phased-in approach to improve the traffic flow to meet the demands of current traffic flow and for the next 20 year horizon considering growth and other proposed developments. (e) A comprehensive report outlining the findings of this investigation and proposed recommendations should be delivered upon completion of the project.

vii) Steel Building Extension: (a) students are required to complete the structural design package including concrete foundations, steel frame, Q-deck, joists and structural stud exterior walls. (b) Provide a cost estimate for the excavation/backfill, concrete, steel, exterior walls, roofing, and exterior finishes.

viii) Penstock Replacement at an active, centuryold small hydro plant. (a) The local power utility requires students to complete the detailed design for a new steel penstock (i.e. alignment for the new penstock, penstock thickness, pier \& anchor block design etc.) and provide detailed design drawings along with a cost estimate to demolish the existing penstock and supply and install a steel penstock. (b) the students will also require the students to assess alternative replacement options to steel and provide cost estimates to supply and install these alternative options.

ix) Tailings Dam Design (a) Design of a tailings management system for a fluorspar mining project. The scope of work includes site seismic evaluation, geotechnical and hydrogeological site characterization, design criteria, dam design, drawings, technical specifications, material take off, cost estimate and final report. (b) define design aspects such as total tailings capacity, density, freeboard requirements, watershed characteristics, discharge levels etc. (c) the type of dam will have to be determined (earthfill, concrete, low permeability core, HDPE liner etc.). (d) Stability analysis along with preliminary hydrological analysis will have to be performed to evaluate the freeboard, spillway and diversion ditch design. Design drawings showing plan and typical dam cross sections will be required.

x) Integrated Design towards LEED Certification of New University Residence Memorial University is in the process of designing and building a new 300+ bed residence for its St. John's campus. The location of the building and the detailed functional requirements have been determined and the design process has commenced. The objective of this project is to take the same design basis (constraints) and search for best practices in integrated sustainable design to see if there are viable alternatives to the approaches found through the more traditional "serial" design process. 


\section{Discussion}

Relatively few problems have been experienced with the operation of the design project although considerable planning and organization is required by the faculty members prior to the commencement of the course. It is necessary to arrange meetings with partners or heads of engineering sections in order to describe the organization and operation of the course and to set up suitable projects. Initially there were difficulties associated with the specification of suitable projects, but these have been alleviated, as local civil engineering firms have become familiar with the objectives of the course. Also, many clients were former students who went through the program.

Considerable tact is necessary when approaching clients in the first instance, particularly when a prospective client suggests an unsuitable project that must be substantially modified or rejected. Priorities must be carefully explained and it is necessary to ensure that the assignment is neither trivial nor totally beyond the students capability.

Normally students are highly motivated and, although this brings considerable benefit, it also causes problems. Many students find it difficult to apportion their workload evenly throughout the semester. The development of a detailed work breakdown structure early on helps to alleviate this difficulty, but constant supervision is still required to ensure that other courses do not suffer because of the extra time devoted to the project. Difficulties related to work load have also been experienced when clients change their mind part of the way through the project. Fortunately this happens rarely. If it does, the course supervisor may have to step in. The model for the capstone projects that the civil engineering program at Memorial has been using for the last 40 years is not the only model. Other universities in North America tend to have variations although the goal is the same. Interested readers should refer to [2] for a survey of capstone courses in North America. From the positive feedback of clients and accreditation visitors over the years, we believe that our model has been highly effective.

\section{Conclusion}

It is of course impossible to measure the educational benefits of integrating professional practice into the academic program as described in this paper. Nevertheless, it is possible to make some subjective and qualitative judgements.
By undertaking capstone design projects in a realistic situation similar to that of an engineering office, students develop special technical abilities and a professional approach to their work. Libraries and Resource centres are used much more frequently than in other courses. Because of the high motivation and interest, the retention of knowledge acquired is high and students begin to develop an understanding of system procedures. Furthermore, the relevance of other academic course becomes more apparent because of the need to apply knowledge gained in these courses to what is perceived to be a "real life" as opposed to an "academic" problem.

Not only students benefit from these approaches. By the time they tackle the project, students are approaching graduation and have about six work terms ( 2 years) in industry. The work they undertake reflects this exposure and information provided by them is normally of considerable value to the client. The students normally spent considerable time on the projects and in terms of monetary value to the client, typically each project is worth about $\$ 20,000$ to $\$ 30,000$ of engineering time, not considering the free expert advice of faculty members. Project reports have commonly been used as design checks or to confirm a proposal made by the client's firm to other agencies.

One major benefit of running a co-operative program with an industry based capstone design project has been the integration of the profession and the university. As more and more practicing engineers become involved in the work of the faculty, the links between university and industry are made stronger. In the long term this can only be very beneficial.

\section{References}

[1] CEAB, 2008. Accreditation Criteria and Procedures, Engineers Canada.

[2] Todd, R. H., Magleby, S. P., Sorenen, C. D., Swan, B. R., and Anthony, D. K., 1995. A survey of Capstone Engineering Courses in North America. Journal of Engineering Education, April. 